therefore has a low equilibrium temperature, probably between $200^{\circ}$ and $220^{\circ}$. The case of ozone is even more complicated, since it absorbs not only at $9.5 \mu$ but also to a certain extent in the visible and very strongly in the ultra-violet below $3000 \AA$.U. Since a not inconsiderable fraction of the sun's radiation (probably more than I per cent.) lies in this region, this amount of heat as well as that abstracted from the visible part of the spectrum has to be accounted for in some form or other. It can only be re-emitted by pure ozone at a wave-length of $9.5 \mu$, and its equilibrium temperature when exposed to sunlight and the earth's radiation would therefore be correspondingly high, probably well above $300^{\circ}$.

The general picture may therefore be drawn in outline as follows. At low heights in the troposphere we have convection and therefore an adiabatic temperature gradient. Above Ix km., at which height the temperature has fallen to the equilibrium radiative temperature, i.e. $220^{\circ}$, convection will be damped out.
From here on one should have a compromise between the radiative equilibrium temperatures of the various active gases. At II km. the effect of water and carbon dioxide will preponderate and a low temperature will obtain, but as one ascends, the carbon dioxide disappears and the water diminishes, whilst the ozone with its high equilibrium temperature will become more and more dominant. Above $60 \mathrm{~km}$. the effect of ozones should outweigh that of the other gases and the air should approach the equilibrium temperature of this gas, i.e. about $300^{\circ}$, as is indicated by the various more empirical arguments we have outlined.

Whether the agreement of all these forms of indirect reasoning is regarded as convincing is of course a matter of personal opinion. Final certainty can only be attained by direct measurement. It is much to be desired that such immediate observations be made at the earliest possible moment, but the expense and difficulty at present seem to be prohibitive.

\title{
Methods and Results of the American Museum Expeditions in the Gobi Desert, I922-25. ${ }^{1}$
}

By Prof. Henry Fairfield Osborn, For. Mem. R.S. NEW volume in the life-history of the earth,
composed up to the present of twenty-four chapters (see table below), has been revealed by the discoveries of the Mongolian Expeditions of the American Museum of Natural History, under the leadership of Roy Chapman Andrews. Central Asia, and especially the region east and south-east of Chinese Turkestan, long remained the terra incognita of geology, palæontology, and, in a minor sense, of geography. In 1900 the lecturer predicted that the unknown highplateau region of Central Asia, rather than the wellknown Asiatic provinces on the south, such as the Siwalik Hills of India, explored by Hugh Falconer (1830-50), would prove to be the chief centre of the origin and distribution of the mammalia from which waves of north mammalian life radiated to the continents of Europe and of North America.

Andrews's expeditions in the three seasons of I922, 1923 , and 1925 , have not only completely verified this prediction, but have also revealed the high Central Asiatic plateau region as the chief home of the terrestrial deinosaurian reptiles of Upper Jurassic and of Cretaceous time. In brief, these discoveries establish Mongolia as a chief centre of northern terrestrial life-history, from the close of Jurassic time onwards to the very close of Pleistocene time.

From the point of view of palæogeography, the outstanding geological discoveries of the expedition are:

First, this Central Asiatic continent of Gobia, as it has been named by Grabau, was for several millions of years extremely favourable to the evolution of reptiles, mammals, insects, and plants, and probably birds as well, hitherto known along the low-lying Cretaceous forelands of western Europe (such as the Wealden of England and Belgium), and in less degree of southern Asia. Secondly, this now terribly desert region of Gobia, traversed only by the gazelle and the wild ass, and thoroughly uninhabitable in the summer season, was abounding in life throughout Upper

1 Abstract of a Jecture delivered by the author to the Geological Society of London on June 23

N O. 2962, VOL. I I 8]
Jurassic, and throughout all Cretaceous and Tertiary time, sparsely forested, traversed by streams and rivers, with a limited seasonal rain-supply like the highplateau region of Central Africa to-day. Thirdly, these dry and stimulating upland conditions of 'Tertiary time, as compared with the densely forested conditions of the Asiatic lowlands, have led to the recent prediction by the lecturer on returning from Iren Dabasu in I 923 , that this region is the most likely one in which to search for the Tertiary ancestors of man, namely, those of Eolithic or Dawn-stone Age, though no traces of man have, as yet, been discovered by the expedition older than those of Lower Palæolithic age. The discovery of human and pre-human remains in Tertiary time has thus become one of the chief remaining objects of the expedition.

During the season of 1925 a great culture-camp, probably of Azilian-Campignian time, was discovered on the eastern slopes of the Altai Range, not far from Shabarakh, and not far from Djadokhta, where the now famous deinosaur eggs were discovered, far north of the Ordos locality explored by Licent and Teilhard de Chardin. In fact, these Upper Palæolithic artisans collected the broken shells of the deinosaur eggs with which to manufacture necklace ornaments, these perforated fossil shells serving as well as the recent eggshells of the giant Struthiolithus, the great ostrich of the Stone Age of Mongolia.

No human fossils have so far been found: the industrial levels are not as yet precisely determinable, but the chief anthropological fact is established that the Stone Age tribes spread over the borders of the Gobi Desert region during the Ice Age, establishing their quarries near the large lakes bordering the Altai Mountains on the east and fed by glacial streams. The geologists of the party have discovered traces of this glacial age along the summits of the Altai Range.

As for methods, by combining a very large caravan for the camel transport, which leaves Kalgan on December I, and reaches the eastern base of the Altai Range on May I, with an automobile train of five to 
seven cars, the expedition had the great advantage of speed over the previous geological explorers who crossed the Desert with camels only. The geologists and palæontologists of the party, Granger, Berkey, and Morris, with two field assistants, also had the advantage of prolonged experience in the field formations of the western United States, which, between the 5 oth and 4 oth parallels of latitude, present conditions remarkably similar to those found in the Desert of Gobi. Raphael Pumpelly in I864, Ferdinand von Richthofen in 1872 , and V. A. Obruchev in 1909, found no fossils, except the single rhinoceros-tooth brought back by Obruchev; and other geologists traversing this region have thought that there were no fossils to be found.

As to geology, the expeditions beginning on April I5, 1922, 260 miles north-west of Kalgan, and encircling in 1922,1923 , and 1925 , the entire Gobi district in a 300o-mile radius, discovered no fewer than twentythree distinct geological formations extending downwards from Lower Pleistocene time into Lower Cretaceous and Upper Jurassic. These have a thickness varying from 50 to 3000 feet, and were deposited either in the great flood-plains of ancient rivers, or in broad river-valleys, or at the base of ancient mountain-chains, or in the torrents of great sandstorms such as the Djadokhta, testifying to the secular vicissitudes of climate, mostly of rainfall, terminating with the pluvial period of the Ice Age, followed by a long period of secular desiccation.
Some of these formations prove to be closely contemporaneous with the Lower Cretaceous Wealden of western Europe, owing to the presence of large iguanodonts, equalling the famous $I$. bernissartiensis of Belgium in size. The oldest are as early as the Oxfordian and Purbeck of Upper Jurassic times. The climax of reptilian life is reached in the marvellous sand-swept deinosaur breeding-grounds (Djadokta formation) of Middle Cretaceous time, where nests of fossil eggs and innumerable skulls and skeletons of Protoceratops are found in almost perfect preservation. This is the richest deinosaur deposit thus far discovered in Eurasia.

As to the fifteen succeeding Tertiary formations, they compose so many unbroken chapters of the history of Mongolian life as extend from the basal Eocene Gashato to Upper Oligocene time, where the giant Baluchitherium occurs, as discovered also in Baluchistan by Cooper of Cambridge, and in Chinese Turkestan by Borissiak of Moscow. The Miocene and the Pliocene periods are represented by four formations.

Thus the scientific staff of the Expedition, between the years 1922 and 1925 , has interpreted one of the most typically desert regions of the entire world by means of the twin sciences of palæontology and geology, and the wilderness of Mongolia now blossoms forth with its glorious story of prehistoric life, as the homeland of the greater number of known upland terrestrial vertebrates.

Stone Age, Tertiary, and Cretaceous Formations of Mongolia, in descending order.

Regions.

Altai Piedmont

Orok Nor basin

Tsagan Nor basin .

Eastern Altai Mts.

Eastern Altai Mts.

Iren Dabasu basin

Orok Nor basin

Uliassutai Trail

Uliassutai Trail

" "

Shara Murun basin
Iren Dabasu basin

Kholobollchi Nö basin

Eastern Altai Mts.

Eastern Altai Mts.

N.-E. of Shabarakh Usi Iren Dabasu basin Oshih basin

Tsagan Nor basin .

$$
\begin{aligned}
& \text { Formations and Thickness } \\
& \text { estimated in feet. }
\end{aligned}
$$

\begin{tabular}{|c|c|}
\hline $\begin{array}{l}\text { Shabarakh U } \\
\text { Orok Nor }\end{array}$ & $\cdot \underset{5-40}{50+}$ \\
\hline Khunuk . & $27-120$ \\
\hline Tsagan Nuru & $50 \pm$ \\
\hline $\begin{array}{l}\text { Gochu } \\
\text { Hung Kureh }\end{array}$ & $\begin{array}{l}1000 \pm f \\
1000\end{array}$ \\
\hline Pang Kiang & 500 \\
\hline Loh . & . 100-1000 \\
\hline Hsanda Gol & . $\quad 3000$ \\
\hline Houldjin . & $30-50$ \\
\hline Elegen : & $0-200$ \\
\hline Baron Sog. & $5-30$ \\
\hline Ulan Gochu & $2-60$ \\
\hline Ardyn Obo & 500 \\
\hline Shara Murun & $200 \pm$ \\
\hline $\begin{array}{l}\text { Tukhum } \\
\text { Irdin Manha }\end{array}$ & $50+$ \\
\hline $\begin{array}{l}\text { Irdin Manha } \\
\text { Arshanto }\end{array}$ & $\begin{array}{r}? \text { roo } \\
40-100\end{array}$ \\
\hline Kholobolchi & \\
\hline Gashato. & ${ }_{300}^{1000} \pm$ \\
\hline & 500 \\
\hline Dohoin Usu & $200 \pm$ \\
\hline Iren Dabasu & 180 \\
\hline Ashile. . & \\
\hline Ondai Sair . & 500 \\
\hline
\end{tabular}

Probable or estimated Geological Age.

Upper Palæolithic
Middle Palæolithic Lower Palæolithic

Lower Pleistocene

Lower Pleistocene

Upper Pliocene to Lower Pleistocene Miocene; age doubtful

Middle Miocene
Middle to Upper Oligocene$$
\text { " }
$$

Middle Oligo"cene

Lower Oligocene

Summit of Ëocene

Upper Eocene

? Middle Ëocene :

Basal Eocene (Palæocene)

Middle Cretaceous

Lower Cretaceous. ? Wealden

Upper Jurassic
Human Culture, Mammalian and Reptilian Life-zones.

? Azilian-Campignian.

? Aurignacian-Mousterian.

? Acheulean or ? Eolithic.

? Equus, ? Mastodon.

? Equus, ? Struthiolithus.

Hipparion. Camelus zone.

Rodents. ? Ochotoma.

Mastodon (Serridentinus) zone.

? ", "',

? Large Titanotheres.

?

Brontops gobiensis zone.

Protitanotherium mongoliense zone.

Amynodon mongoliensis.

Eudeinoceras, Andrewsarchus zone.

Lophiodonts-Schlosseria zone.

Coryphodon zone.

Prodeinoceras zone. Palæostylops.

Protoceratops andrewsi zone.

Deinosauria, Crocodilia, Chelonia zone.

Iguanodont. Ornithomimidæe.

Psittacosaurus zone. Asiatosaurus.

Prodeinordon.

Protiguanodon zone.

\section{The British Association at Oxford.}

$\mathrm{BY}^{\mathrm{Y}}$ the time that the present issue of NATURE is in the readers' hands, the meeting of the British Association for the Advancement of Science will be in full progress. The Sheldonian Theatre, where Mr. Disraeli made the celebrated announcement that he was "on the side of the angels," will have been the scene of yet another important gathering; and the chief social events of the meeting, namely, the receptions by the Vice-Chancellor, the Mayor, and the Dean, Canons, and students of Christ Church, will have taken place at the Examination Schools, the Town Hall, and Wolsey's great foundation respectively.

NO. 2962, VOL. II 8 ] 